\title{
Prototype Development of Motorbike Towing Hook Towards Authorized Mechanic Perception and Investigation
}

\author{
Rahman Hakim ${ }^{1}$ Muhammad Hasan Albana ${ }^{1}$ Widodo $^{1}$ Hanifah Widiastuti $^{1}$ and \\ Wahyu Caesarendra ${ }^{2, *}$ \\ ${ }^{1}$ Department of Mechanical Engineering, Politeknik Negeri Batam, Jl. A. Yani, Batam Center, Kota Batam 29461, \\ Indonesia \\ ${ }^{2}$ Faculty of Integrated Technologies, Universiti Brunei Darussalam, Jalan Tungku Link, Gadong BE1410, Brunei \\ Darussalam \\ *Corresponding author. Email: wahyu.caesarendra@ubd.edu.bn
}

\begin{abstract}
The research aims to find the authorized mechanic perception of the towing hook's development to lay at the motorbike's front section. A prototype invention of a motorbike towing hook was found in 2018. However, it has never been tested for function by an official motorbike dealer in Batam. The research method used is quantitative research by analyzing questionnaire data, which is processed by SPSS. The mechanical data population was 18 people with Slovin's method, a proportional random sample of 17 samples. The analysis method for testing the validity (Bivariate Pearson) and reliability (Alpha Cronbach) was carried out to obtain the desired questionnaire data. Based on the calculation data, the validity value of $r_{\text {pearson }}=0.701$ is valid. In contrast, the calculation results of the reliability test are the results of $r_{a c}=0.864$ with a sufficient level of reliability. The investigation data based on the perception method are valid and reliable. Therefore, this invention still requires improvements from design to manufacture before being mass-produced.
\end{abstract}

Keywords: Motorbike Towing Hook, Prototype, Mechanic Perception

\section{INTRODUCTION}

In Indonesia, the need for mobility makes people unable to gain from motorized vehicles. Most motorized vehicles in Indonesia today are two-wheeled vehicles, which account for $82 \%$ of the total population (bps.go.id). The high number of motorbike users is often not conducted by awareness to maintain motorbike [1]. We frequently encounter motorbikes by their ages that strike on the streets [2]. Some situations that often cause a motorbike to strike include the driver awareness [3], the engine overheating [4], flat tire [5], broken chains [6], fuel impurity [7], and malfunction of ignition spark [8], even dirty fuel filters (astramotor.co.id). Striking motorbike users often ask other motorbike riders to help to use unsafe methods [9]. However, many are applied in the community, as shown in Fig. 1a.

This research was conducted to develop a motorbike towing hook that could help striking motorcyclists with safer methods. As shown in Fig. 1b, the towing device (invention) developed results from a design that has been patented or published [10].

In the early 2020s, the invention prototyped, and a feasibility test conducted by Politeknik Negeri Batam students. As shown in Fig. 1c, this test carried out with a maximum load (three adults) of the rider and his passengers and both pulled by motorbike and a car in general. 


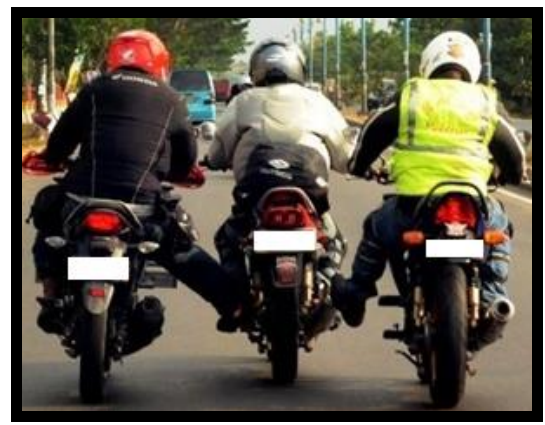

(a)

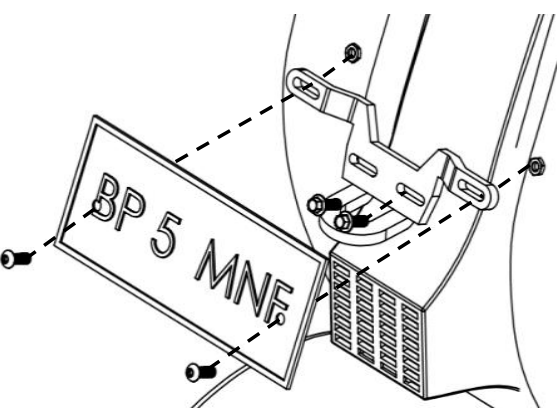

(b)

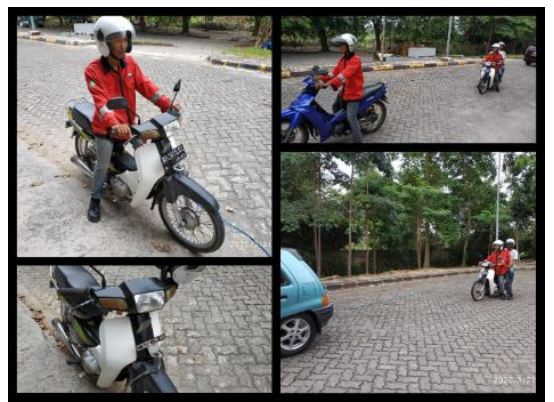

(c)

Figure 1. (a) An alternative solution to help the rider from getting strikes on the street, (b) Detail drawing from the patent application, (b) First phase of the invention on the road trial.

This study aims to determine how valid and reliable the application of prototype invention is from the official mechanics (Dealers) of motorbikes in Batam city, Indonesia.

The questionnaire was conducted due to carrying out a study that required valid and reliable data. The testing method on a research sample has a purpose to expect the correct data, accurate and precise, in performing its functions. Questions are considered reliable if the respondent's answers are consistent from time to time.

Validity is a testing method of a measuring instrument used. The data is declared valid, showing the measuring instruments to obtain valid data [11]. Therefore, a valid measuring instrument is an instrument that is appropriate to do. Meanwhile, reliability is the value of the measurement results of the measuring instruments used in research into social activities and production data with $\mathrm{r}_{\mathrm{ac}}$ values $>0.6$ or can be said to be reliable. When measured and analyzed, the data has a level of consistency among respondents [12].

\section{MATERIALS AND METHODS}

The data used in this study are data obtained by field surveys through the distribution of questionnaires to respondents - population data of 18 official mechanics (Dealers) motorbikes from the four largest manufacturers. The data were collected from 9 dealers from 4 different motorcycle brands in Batam city, used in Slovin's equation to determine the number of samples as initial data for questionnaire distribution.
The Likert scale is a method of using a scale used to measure the attitudes, opinions, and perceptions of a person or group of people about the significance of user satisfaction [13], [14]. Moreover, a Likert scale measurement is carried out and analyzed using five answer choices commonly done by researchers. In contrast, the way to measure Likert's scale is to confront a resource person with a statement. Then be asked to answer seven choices of answers where the answer value has a different answer value [15].

In this study, closed statements used with a range of rating interval scales, namely: Strongly agree: 7, Strongly Agree: 6, Agree: 5, Doubtful: 4, Less agree: 3, Disagree: 2, and Strongly disagree: 1 .

The population collects prospective respondents consisting of objects or subjects with the qualities and characteristics determined by researchers to study and retrieve data [16]. In this study used the Slovin's formula to determine the number of samples.

A normality test is a testing method that is carried out to evaluate data distribution in a group of data, whether the data distribution normally distributed or inverse. According to Shapiro, the normality test uses $<50$ data samples. While testing, data is declared to be normally distributed if the significance value is more than $5 \%$ (Sig.>0.05). One of the formulae that can use to measure the validity of them is the Shapiro-Wilk's equation.

Validity testing criteria which are said to be successful (valid) if the value of $r$ count is more than 
$r_{\text {table }}$ by considering the number of samples and the results of field observations. One of the formulae that can use to measure the validity of them is the Bivariate Pearson equation.

The Cronbach alpha formula was used as the reliability test to generate the questionnaire in this study, which was carried out with the SPSS program's help.

The reliability testing criterion is successful if the alpha coefficient value is larger than the significance level of $60 \%$ or 0.6 . Furthermore, Maulana explains that valid and reliable instrument data is factual research results data and has a similarity between the data collected and the data that has been observed [17].

\section{RESULTS AND DISCUSSION}

Respondent data: Table 1 shows the variation of respondents after applying Slovin's theory. It illustrates the distribution of official motorbike mechanics' competency level from the four largest manufacturers located in Batam city. The questionnaire data collected during the COVID-19 pandemic season. Each official workshop only operates two mechanics a day and randomly takes the data sample with the Proportional Random Sample method.

Table 1: Distribution Data of Respondent

\begin{tabular}{clcc}
\hline \multicolumn{2}{c}{ Respondent } & Amount & Percentage \\
\hline \multirow{2}{*}{ Motorbike Brands } & Dealer 1 & 4 & $23.53 \%$ \\
& Dealer 2 & 10 & $58.82 \%$ \\
& Dealer 3 & 1 & $5.88 \%$ \\
& Dealer 4 & 2 & $11.76 \%$ \\
& Total & $\mathbf{1 7}$ & $\mathbf{1 0 0 \%}$ \\
\hline Tenure & -5 Years & 10 & $58.82 \%$ \\
& >5 Years & 7 & $41.18 \%$ \\
& Total & $\mathbf{1 7}$ & $\mathbf{1 0 0 \%}$ \\
\hline
\end{tabular}

Normality Test (Shapiro Wilk's): Table 2 shows the usage of Shapiro-Wilk's method. The results of the questionnaire present a significance value of $6.7 \%$. The normality test is within an acceptable range and normally distributed if the significance test's value is larger than $5 \%$. Furthermore, Fig. 2a depicts the distributed questionnaire values distribution and shows a normally distributed polynomial graph pattern. Figure $2 \mathrm{~b}$ shows the questionnaire values' data distribution is distributed around the fit line, both above and below the fit line. The data is in the middle of the diagram and fit line, so in other words, the variables are normally distributed.

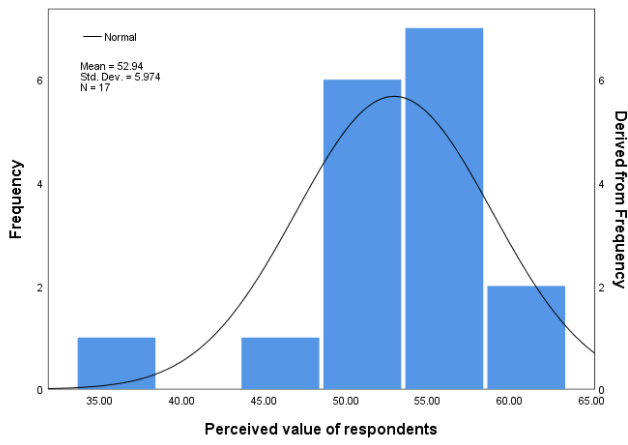

(a)

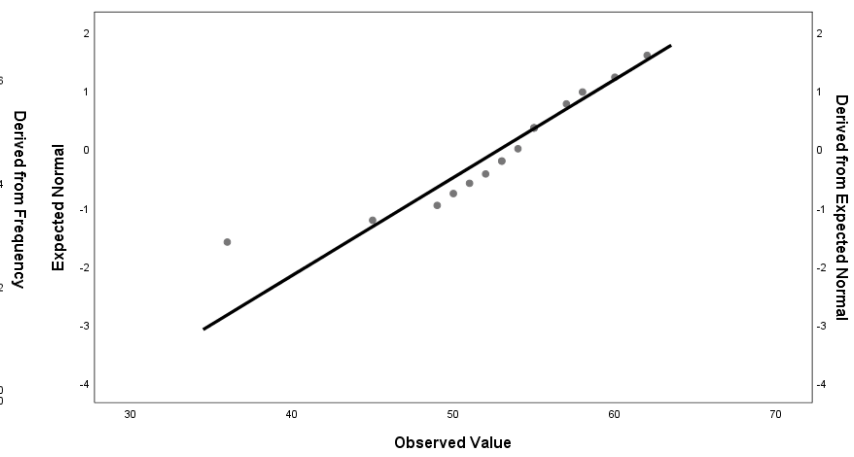

(b)

Figure 2: Distribution of normality test; (a) Perceived value of respondents, (b) Expected normal data. 
Table 2: Result of Normality Test

\begin{tabular}{lcccccc}
\hline & \multicolumn{3}{c}{ Kolmogorov-Smirnova } & \multicolumn{3}{c}{ Shapiro-Wilk } \\
\cline { 2 - 7 } & Statistic & df & Sig. & Statistic & df & Sig. \\
\hline Perceived value of respondents & .151 & 17 & $.200^{*}$ & .900 & 17 & .067 \\
\hline *. This is a lower bound of the true significance. & & & & & \\
a. Lilliefors Significance Correction
\end{tabular}

Validity and Reliability Test: Table 3 describes the analysis of the validity and reliability of each respondent. The validity calculation value from SPSS output data of $r_{\text {pearson }}=0.701$ is valid for the validity of each question. The estimated value using the Bivariate
Pearson method must be above 0.482 . The reliability calculation value from SPSS output data of $r_{a c}=0.864$ with a sufficient level of reliability. For each query, it is declared reliable, which must have a calculated value using the Cronbach's alpha method above 0.6.

Table 3: Respondent Data Tabulation of the Invention Prototype Test Results

\begin{tabular}{|c|c|c|c|c|c|}
\hline \multirow{2}{*}{ No. } & \multirow{2}{*}{ Questions } & \multicolumn{2}{|c|}{ Validity Test } & \multicolumn{2}{|c|}{ Reliability Test } \\
\hline & & $\mathrm{r}_{\text {pearson }}$ & rtable & $\mathrm{rac}_{\mathrm{ac}}$ & rable \\
\hline 1 & (X01) Novelty: I have never seen this tool before. & 0.615 & 0.482 & 0.858 & 0.6 \\
\hline 2 & (X02) Novelty: I find this tool simple but very useful & 0.771 & 0.482 & 0.842 & 0.6 \\
\hline 3 & $\begin{array}{l}\text { (X03) Convenience: I find the tool easy to use (Load - Unloading, } \\
\text { less than } 10 \text { minutes) }\end{array}$ & 0.616 & 0.482 & 0.869 & 0.6 \\
\hline 4 & $\begin{array}{l}\text { (X04) Convenience: I find this tool easy to use (Male or Female, } \\
\text { Teenager or Adult) }\end{array}$ & 0.787 & 0.482 & 0.839 & 0.6 \\
\hline 5 & $\begin{array}{l}\text { (X05) Design: I feel the shape of this tool is excellent and suitable } \\
\text { for mass production }\end{array}$ & 0.713 & 0.482 & 0.848 & 0.6 \\
\hline 6 & (X06) Design: I feel this tool is reliable and has a long service life & 0.530 & 0.482 & 0.868 & 0.6 \\
\hline 7 & $\begin{array}{l}\text { (X07) Safety: I feel that this tool will not damage the motorbike } \\
\text { when used }\end{array}$ & 0.884 & 0.482 & 0.824 & 0.6 \\
\hline 8 & $\begin{array}{l}\text { (X08) Safety: I feel this tool, when used, will not harm other } \\
\text { drivers }\end{array}$ & 0.704 & 0.482 & 0.848 & 0.6 \\
\hline 9 & $\begin{array}{l}\text { (X09) Method: I find it preferable to use } 2 \text { meters of steel wire } \\
\text { rope or plastic wire instead of a car tow rope's standard length. }\end{array}$ & 0.693 & 0.482 & 0.850 & 0.6 \\
\hline
\end{tabular}

Table 4: Classification of Tenure

\begin{tabular}{llcccc}
\hline & Classification & N & Mean & Std. Deviation & Std. Error Mean \\
\hline \multirow{2}{*}{ Observation } & Tenure $<5$ years & 10 & 52.70 & 6.734 & 2.129 \\
\cline { 2 - 6 } & Tenure $>$ 5years & 7 & 53.29 & 5.187 & 1.960 \\
\hline
\end{tabular}

Table 5: Independent Sample Test

\begin{tabular}{|c|c|c|c|c|c|c|c|c|c|c|}
\hline & & \multicolumn{2}{|c|}{$\begin{array}{c}\text { Levene's Test } \\
\text { for Equality of } \\
\text { Variances } \\
\end{array}$} & \multicolumn{7}{|c|}{ t-test for Equality of Means } \\
\hline & & \multirow[b]{4}{*}{$\mathrm{F}$} & \multirow[b]{4}{*}{ Sig. } & \multirow[b]{4}{*}{$\mathrm{t}$} & \multirow[b]{4}{*}{ df } & \multirow{4}{*}{$\begin{array}{l}\text { Sig. (2- } \\
\text { tailed) }\end{array}$} & \multirow{4}{*}{$\begin{array}{c}\text { Mean } \\
\text { Difference }\end{array}$} & \multirow{4}{*}{$\begin{array}{l}\text { Std. Error } \\
\text { Difference }\end{array}$} & \multirow{3}{*}{\multicolumn{2}{|c|}{$\begin{array}{c}95 \% \\
\text { Confidence } \\
\text { Interval of the } \\
\text { Difference } \\
\end{array}$}} \\
\hline & & & & & & & & & & \\
\hline & & & & & & & & & & \\
\hline & & & & & & & & & Lower & Upper \\
\hline \multirow{2}{*}{ 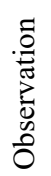 } & $\begin{array}{c}\text { Equal variances } \\
\text { assumed }\end{array}$ & .265 & .614 & -.193 & 15 & .850 & -.586 & 3.037 & -7.058 & 5.887 \\
\hline & $\begin{array}{c}\text { Equal variances } \\
\text { not assumed }\end{array}$ & & & -.202 & 14.787 & .842 & -.586 & 2.894 & -6.763 & 5.591 \\
\hline
\end{tabular}


Furthermore, the respondent's perceptions of this invention regarding the design's reliability obtained the lowest $r$-person value is 0.530 , which is found in query number six, as presented in Table 3 . While for other items, the average was above 0.482 . However, if the query number six is compared with r-table, the value is still higher. Consequently, it can be stated that the query number six is valid. As for the reliability test results, all queries are declared reliable because they are above 0.6 .

According to the result presented in Table 4, the number of mechanics with a service life of fewer than 5 years is ten people. The number of mechanics with tenure of $>5$ years is seven people. The average perception value of mechanics with a service life of fewer than five years is 52.70. Furthermore, the mean score of mechanics perceptions with tenure $>5$ years was 53.70. Therefore, statistically descriptive, it can be concluded that there are differences in the average perception.

One way to prove whether there is a significant difference is to analyze the independent samples test results. Based on the data in Table 5, the Sig. Levene's Test for Equality of Variances is $0.614>0.05$. It means that the data variance between the mechanic group with tenure fewer than 5 years and the mechanic group with tenure for $>5$ years is homogeneous. So, the output table's interpretation is an independent samples test based on the value contained in the equal variance assumed table.

Furthermore, based on the output table above in the equal variances assumed the Sig. 2-tailed of $0.850>0.05$. Therefore, as the basis for decision making in the independent sample t-test, it can be concluded that $\mathrm{H}_{0}$ is accepted, and $\mathrm{H}_{1}$ is rejected. Determines that there is no significant difference between mechanics perceptions with tenure fewer than 5 years with mechanics perceptions with tenure for $>5$ years.

The difference between the mean perception of mechanics with tenure fewer than 5 years and mechanics with tenure for $>5$ years is -0.586 or 52.70 - 53.29 (Table 4). The difference between these differences is -7.058-5.887 (95\% confidence interval of the difference lower upper).

\section{CONCLUSION}

The usage of Shapiro-Wilk's method presents a significance value of $6.7 \%$. It is normally distributed if the value of the significance test is $>5 \%$. The validity value from the equation of $r_{\text {pearson }}=0.701$ can be said valid because the minimum value of Bivariate Pearson's method from the statistic table is 0.482 . Furthermore, the reliability value from the equation of $\mathrm{r}_{\mathrm{ac}}=0.864$ can be a sufficient reliability level because Cronbach's alpha method's minimum value is 0.6 . The Significance test has been done using Significance
Levene's Test for Equality of Variances is 0.614, which is $>0.05$. The equal variances assumed the Sig. 2-tailed is 0.850 which is $>0.05$. It means there is no significant difference between mechanics perceptions with tenure fewer than 5 years with mechanics perceptions with tenure for $>5$ years.

\section{REFERENCES}

[1] Y. Khandelwal, S. Anwar, S. Agarwal, V. Tripathi, and P. Pandey, "A Framework for Enhancing the Security of Motorbike Riders in Real Time," in Intelligent Computing in Engineering, 2020, pp. 275-281.

[2] J. Wong, Y. Chung, and S. Huang, "Determinants behind young motorcyclists' risky riding behavior," Accid. Anal. Prev., vol. 42, pp. 275-281, 2010.

[3] T. Bellet and A. Banet, "Towards a conceptual model of motorcyclists' Risk Awareness : A comparative study of riding experience effect on hazard detection and situational criticality assessment," Accid. Anal. Prev., vol. 49, pp. 154-164, 2012.

[4] Z. Wang, "Research of motorcycle exhaust pipe fracture failure," J. Mech. Strength, vol. 37, no. 6, pp. 1159-1162, 2015.

[5] H. Purnomo, F. Kurnia, and R. I. Virdyanawaty, "The Design of Auxiliary Tool for Flat Motorcycle Tires using the Axiomatic Design Method," in Annual Conference on Industrial and System Engineering (ACISE), 2019.

[6] H. Santoso, "Sound Recognition of Four Stroke Manual Transmission Motorcycle Engine's Damage," in 2nd International Conference on Engineering and Applied Sciences, 2020.

[7] P. Sakthivel, K. A. Subramanian, and R. Mathai, "Comparative studies on combustion, performance and emission characteristics of a two-wheeler with gasoline and 30\% ethanolgasoline blend using chassis dynamometer," Appl. Therm. Eng., vol. 146, pp. 726-737, 2019.

[8] D. Huang, J. Jang, P. Lin, and B. Chen, "Effect of ignition timing on the emission of internal combustion engine with syngas containing hydrogen using a spark plug reformer system," Energy Procedia, vol. 105, pp. 1570-1575, 2017.

[9] H. M. Naqvi and G. Tiwari, "Factors Contributing to Motorcycle Fatal Crashes on National Highways in India," in Transportation Research Procedia, 2017, vol. 25, pp. 2084-2097. 
[10] R. Hakim, M. H. Albana, H. Widiastuti, K. Rahman, and H. Saputra, "Alat Bantu Derek Sepeda Motor Bebek Sederhana," S00201811110 (Indonesian Patent Pending), 2018.

[11] Sugiyono, Metode Penelitian Bisnis. Bandung: Alfabet Jakarta, 2009.

[12] R. Irawati, A. Wirangga, and S. W. Hati, "Analisa Kepuasan Pelanggan Bandar Udara Hang Nadim Batam," J. Integr., vol. 4, no. 2, pp. 159-167, 2012.

[13] N. L. Arifin and M. H. Albana, "Kinerja Mesin Pengupas Serabut Kelapa Politeknik Negeri Batam ditinjau dari Persepsi Pengguna," J. Integr., vol. 8, no. 1, pp. 37-41, 2016.

[14] S. Janti, "Prosiding Seminar Nasional Aplikasi Sains \& Teknologi (SNAST) 2014 Yogyakarta, 15 November 2014 ISSN: 1979-
911X," in Prosiding Seminar Nasional Aplikasi Sains \& Teknologi (SNAST) 2014, 2014, no. November, pp. 155-160.

[15] W. Budiaji, "Skala Pengukuran dan Jumlah Respon Skala Likert (The Measurement Scale and The Number of Responses in Likert Scale)," Ilmu Pertan. dan Perikan., vol. 2, no. 2, pp. 127-133, 2013.

[16] I. H. Rani and M. Mayasari, "Pengaruh Penilaian Kinerja Terhadap Kinerja Karyawan Dengan Motivasi Sebagai Variabel Moderasi," J. Akuntansi, Ekon. dan Menejemen Bisnis, vol. 3, no. 2, pp. 164-170, 2015.

[17] Y. Maulana, M. Astuti, and S. Surachman, "Analisis Pengaruh Servqual Terhadap Kepuasan Serta Loyalitas Mahasiswa (Studi Kasus Pada Jurusan Teknik Mesin Di Universitas 'XYZ'),' Rekayasa Mesin, vol. 3, no. 1, pp. 258-267, 2012. 